\title{
Persuasive Language in Political Campaign
}

\author{
FAHRIA MALABAR \\ Universitas Negeri Gorontalo \\ fahria@ung.ac.id
}

\begin{abstract}
This study is aimed at exploring the persuasive language strategies used by the candidates of mayor of Gorontalo in the mayoral electoral campaign of 2018. The data, in form of utterances, were taken from the speeches of their political campaign by using video recording. After the data were collected, those were firstly classified into the types of persuasive language strategies, then analyzed and interpreted regarding the function and the way the speaker used those strategies to persuade the audience.The result showed that the three candidates used the similar strategies to influence the audience of their political campaign. Those strategies are reason and logic, evidence, attack, appeal to a sense of justice, appeal to the hip-pocket nerve, appeal to patriotism, repetition, and colloquial language. However, based on the interpretation, the different political background of the candidates influenced the way they used the strategies. Therefore, this study is expected to give theoretical knowledge about the form of persuasive strategies used in speech in political campaign.
\end{abstract}

Keywords: persuasive strategy; political campaign

\section{INTRODUCTION}

Electoral campaigns are events when some people, in this case the candidates of the election, try to attract other people's attention to be in their sides. Frequently, the candidates use particular way of communication to persuade the voters. This way of communication is called persuasive language. The term persuasive language is defined as the communicative strategies used by people to persuade and change other people's perspectives and attitudes.

Persuasive language is used in many fields. Some of them are advertisements and politics. In advertisement field, the persuasive language is used by the producers to persuade the customers to buy their products. Along with the previous idea, in political field, the persuasive language is used to bear the societies' concerns to the politicians and choose their sides. Furthermore, the politicians use some techniques of persuasion to achieve their intentions. The techniques that are used determine the success of the persuasion.

A teaching resources of persuasive language, provided by Supporting Australian Creative Communities, said that the persuasive language usually include technique, as well as emotions used by the speakers or the writer. In this particular case, persuasive techniques are related with the using of some particular language features which are used by the candidates to convince the societies, such as adjective, adverb, emotive language, colloquial language, and etc. The candidates also often appeal to some specific emotions to make the audience believe on what they are saying. These emotion appealing could be money, fairness, fear, family, etc. In addition, this teaching resources of persuasive language said that it is also important to consider the tone, which means the feeling of the speech. Tones also help the speakers to attract people attention then choose their sides. In conclusion, persuasive techniques, emotions, and tones help the candidates to form a persuasion.

Nowadays, some regions in Indonesia are in the time of electoral campaign. Some regencies and cities of Indonesia are going to vote for their regents and mayors. The candidates are doing campaigns in their areas to persuade and convince the societies to vote them. One of 
the cities in Indonesia which is in the time of local electoral campaign is Gorontalo city. In this time, this city has three candidates who are competing to be a mayor. They are MT, as the incumbent, AD who had ever be the Gorontalo Mayor in the period of 2008-2013, and RP who is the former regent of Boalemo, one of regencies in Gorontalo Province.

Based on those previous explanations, the researcher is interested in conducting this study which is objected to investigate the persuasive language used by the candidates of Gorontalo mayoral election to persuade the voters.

\section{LITERATURE REVIEW LANGUAGE IN POLITICS}

Language is a tool of communication. It is used to fulfill the need of human being as a social creature. Jacobson in Georgakopoulou and Goutsos (2003) state that there are some function of language. They are referential function, emotive function, phatic function, poetic function, metalinguistic function, directive function, and contextual function. Based on those function, language surely plays important role in politics. It is also supported by Bev in Razei and Nourali (2016) who said that "language is a powerful tool in politics and politicians are its users for bad and good purposes". This thought infers that as a tool of communication, language is not only used to deliver ideas and feeling, but is also used by some people to persuade other people to achieve their purposes.

Persuasion and rhetoric are usually involved in politics. It means that when we talk about political language, we certainly talk about rhetoric. It is in line with the definition of rhetoric according to Longman dictionary, which defined rhetoric as "the art of using language, especially public speaking, as a means to persuade". Charteris-Black in Kulo (2009: 3) suggested that in political discourse, the effectiveness of the speakers are defined by the rhetorical strategies used, as well as the appealing to emotion to the listeners.

\section{PERSUASIVE LANGUAGE STRATEGIES}

According to Aristotle in Edlund, there are three strategies used to persuade the listeners. They are ethos, logos, and pathos. Ethos means the speaker's character or image, logos means logical argument, whereas pathos means the emotions of the audience.

Additionally, there are several techniques used in communication to persuade the audience. Those persuasive techniques are as follows: analogy, anecdotes, appeal to a sense of justice, appeal to the hip-pocket nerve, appeal to patriotism, attacks, emotive languages, evidence, generalization, inclusive languages, overstatement / exaggeration / hyperbole, reason and logic, repetition, rhetoric question. Those strategies of persuasive communication can be included into the techniques proposed by Aristotles: logos, ethos, and pathos.

\section{METHOD}

This study is conducted by using qualitative method. This type of methodology is considered to be the appropriate method because this study is designed to get understanding about social phenomenon. This is supported by Clissett in Pacho (2015) who said that qualitative research attempts to make sense of people's experience, perception, beliefs, attitudes and behavior in a given cultural context.

The site of this study is Gorontalo city, as the location of mayoral electoral campaign. These mayoral electoral campaigns have started from Januari and have finished in April. Through these several months the three candidates are competing to attract the people trust to be the mayor of Gorontalo city. 
The data, which are the utterances that contain persuasive strategies, are collected through video recording. The data collected are audiovisual data in form of videotape. These are done to provide the researcher a real situation data, so that she can interpret those data by considering the real context situation.

The data are analyzed through several steps, they are transcribing, identifying, classifying, analyzing, and interpreting the data.In the step of transcribing, the video recordings are being transcribed into written form, so that the data wanted are clearly and easily identified.The result of the data transcription then continue to the identifying step. Not only the data from the transcription, in this step, the data from the campaign billboard are also be identified. The identification is related to the main data of this study. Moreover, the data are the utterances and sentences indicating the persuasive strategies used by the candidates. So, it can be said that the data identified from the sources of the data are sentences and utterances containing the persuasive strategies.After identifying step, the data are then proceed to the next step called classification. The data are classified into the three persuasive strategies suggested by Aristotle. They are logos, ethos, and pathos.After the data have been classified, they are then analyzed also using Aristotle theory about persuasive strategies. The researcher gives a clear explanation about the language which the candidates used to persuade the audience in relation with the strategies they used. In this step, the researcher also consider some of the persuasive techniques provided by a guide to understanding persuasive language. They are adjectives, adverbs, alliteration, analogy, anecdote, attacks, bias, colloquial language, connotation, cliché, description, emotive language, euphemism, evidence, expert opinion, generalization, hyperbole, inclusive language, logic, metaphor, pun, sarcasm, simile, rhetorical question, and repetition.

\section{FINDINGS AND DISCUSSION}

Gorontalo Mayoral electoral campaigns of 2018, which are the data of this research, were presented by three teams of the candidates. The first candidates are AD and HSH, the second candidates are MT and RFK, and the third candidates are RP and RM. The aim of this research is to investigate the persuasive language used by the candidates to persuade the voters to choose them as mayor of Gorontalo city. Based on the observation, the campaigns were not only delivered by those candidates, but also the persons who had capability in presenting the programs and persuading the audiences. However, the data taken are just the speeches which are delivered by the candidates of mayor and vice mayor of Gorontalo City 2018.

In this chapter, the techniques of persuasion used by every candidate are presented. The explanation of those techniques is analyzed by using persuasive techniques which are proposed by Aristotles -logos, ethos, and pathos- as well as considering several persuasive strategies, namely analogy, anecdotes, appeal to a sense of justice, appeal to the hip-pocket nerve, appeal to patriotism, attacks, emotive language, evidence, generalization, inclusive language, overstatement / exaggeration / hyperbole, reason and logic, repetition, and rhetoric question.

\section{PERSUASIVE LANGUAGE USED BY AD AND HSH}

$\mathrm{AD}$ as one of the candidates of Gorontalo Mayor 2018 is a former of Mayor of Gorontalo who served one term, 2008 - 2013, before defeating by MT as the current mayor of Gorontalo. In Mayoral election of 2018, AD is accompanied by HSH as the vice mayor candidate.

In delivering the speeches, AD often used sarcasm to attack the other candidates to persuade the voters. According to the data, this candidates used several strategies of persuasive language in their campaigns. Those strategies are appeal to a sense of justice, appeal to the hippocket nerve, appeal to patriotism, attacks, emotive language, evidence, rhetoric question, and 
colloquial language. Those strategies are then analyzed based on the theory of persuasive language proposed by Aristotle, which are logos, ethos and pathos.

The following data present persuasive strategies used by AD and HSH in their political campaigns. Most of the utterances include in the data used not only one strategy in one data, but generally used two or more strategies as a combination in one data. The analysis are clearly presented in the following explanation of finding.

As previously mentioned, logos refers to the logic and reasoning in the message. According to the data, there are some persuasive strategies used by AD and HSH which can be categorized as logos. They are praise, attack, repetition, and evidence.

Datum 1:

"Bapak ibu yang saya hormati, sebenarnya pada masa pemimpinan pak Adhan, kota Gorontalo cukup berhasil. Baik menuntaskan kemiskinan, peningkatan ekonomi rakyat, infrastruktur yang ada. Menata jalan dan sebagainya. Membangun mall yg sekarang ini kita nikmati."

This datum was uttered at the beginning of the speech to introduce the first mayoral candidate, who was AD. The speaker told the audience that at his one term of servicing Gorontalo city as a mayor, AD had actually successful enough. The speaker said that AD had eliminated the poverty, had enhanced the economy and infrastructure, also had built the only one shopping mall in Gorontalo. By telling these, the speaker wanted to lead the audience's point of view about the candidate.

From the preceding explanation, it can evidently said that the speaker used praise as the persuasive strategy. The beginning of his utterance which said "sebenarnya pada masa pemimpinan pak Adhan, kota Gorontalo cukup berhasil", was a form of compliment that aimed at bringing the voters' positive viewpoint about the candidate. In this datum, the speaker also used evidence in form of anecdotal evidence, which was the evidence that was collected from information that people said. The utterance "menuntaskan kemiskinan, peningkatan ekonomi rakyat, infrastruktur yang ada. Menata jalan dan sebagainya. Membangun mall yang sekarang ini kita nikmati." suggested that the speaker got information about the successful projects which had been done by the candidate. The phrase "yang sekarang ini kita nikmati" which means "that we experience now" added more persuaded belief that the candidate had ever been in the mayoral position and had victoriously administered some projects that now can be enjoyed by the societies.

From the description, it can undoubtedly concluded that in this datum, the speaker used two strategies, they are praise and evidence. This sequence strategies helped the speaker to encourage the voters to be in the same attitude with him. So that, his objective to influence the voters to vote his mayoral candidate could be accomplished.

Datum 2:

"Contohnya program lahir sampai mati, 8 program lahir sampai mati, gratis lahir sampai mati, sampai pada hari ini masyarakat sudah tahu. Masyarakat sudah rasakan, mana bantuan 5 juta? tidak pernah ada. Mana pendidikan gratis? tidak pernah ada. Kita berani untuk menyatakan ini, karena didalam APBD, selama 4 tahun pa Marten memimpin kota ini tidak ada anggaran untuk pendidikan gratis. Tidak ada."

The speaker of this datum was HSH which was the first candidate of vice mayor of Gorontalo. In this datum, the speaker was talking about the programs of all the candidates of Gorontalo Mayor of 2018. At the beginning, the speaker said that all the candidates have good programs for societies. But then he questioned whether or not the candidates can realize their programs when they are elected. Furthermore, the speaker criticized one the opponent by 
saying that the programs which were previously proposed are not realized. It is shown in the utterances "Masyarakat sudah rasakan, mana bantuan 5 juta? tidak pernah ada. Mana pendidikan gratis? tidak pernah ada. Kita berani untuk menyatakan ini, karena didalam APBD, selama 4 tahun pa Marten memimpin kota ini tidak ada anggaran untuk pendidikan gratis. Tidak ada.". By considering the context and the content of the utterances delivered, it can be concluded that the speaker used attacks as persuasive strategy to attract the voters' attention.

While using attack as persuasive strategy to persuade the voters, this candidate used repetition as well. In the utterances "Masyarakat sudah rasakan, mana bantuan 5 juta? tidak pernah ada. Mana pendidikan gratis? tidak pernah ada. Kita berani untuk menyatakan ini, karena didalam APBD, selama 4 tahun pa Marten memimpin kota ini tidak ada anggaran untuk pendidikan gratis. Tidak ada.", the candidate committed two repetition. He repeated phrase "tidak pernah ada" twice and "tidak ada" twice. He used repetition to emphasize that the opponent could not realize projects he proposed in his previous term as the mayor of Gorontalo.

Attack and repetition were used in the same utterance to build the audience attention as well as to highlight the important point that the candidate wanted to be emphasized. The combination of those strategies can finally stimulate the audiences to be in the same opinion with the speaker.

Datum 3:

"sikap pak Adhan dengan jiwa semangat peduli terhadap kepentingan rakyat itu penting bagi seorang pemimpin. Untuk melindung rakyatnya dari kehancuran moral, terjerumus terhadap perbuatan maksiat, minuman keras, .......Sikap peduli melindungi kehancuran keimanan dari rakyatnya, kehancuran agama ini..."

Datum 4:

"Empat tahun pak Marten memimpin kota Gorontalo, koonga beroperasi lagi, minuman keras menyebar di mana-mana, seleb terminal sekarang seperti apa? tangga 2000 seperti apa?"

In these two data, the candidate firstly explained about the programs that have successfully effectuated by AD, which was the first candidate of mayor of Gorontalo, as well as the former Mayor of one term since 2008 until 2013. He previously mentioned that AD has prosperously exterminated alcohol trade and consumption, also the prostitution. After giving praise to his own candidate of Gorontalo Mayor, the speaker who was the candidate of vice mayor of Gorontalo gave comparison of what his mayoral candidate had done with what the opponent candidate who was also the incumbent had done. He said that in four years of serving Gorontalo city as a mayor, the alcohol trade and consumption, along with the prostitution had re-operated.

From the datum 4, the speaker utterance "Empat tahun pak Marten memimpin kota Gorontalo, koonga beroperasi lagi, minuman keras menyebar di mana-mana, seleb terminal sekarang seperti apa? tangga 2000 seperti apa?" can be classified as attack strategy by the reason of using this strategy to be dissident on the opponent who was mentioned in the utterance. He wanted to show the audience that his mayoral candidate was better that the opponent. Attack strategy in datum 4 was preceded by praise strategy which was used to convince the voters that they were in the right side. It can be seen in the utterance of datum 3 given by the speaker, "sikap pak Adhan dengan jiwa semangat peduli terhadap kepentingan rakyat itu penting bagi seorang pemimpin. Untuk melindung rakyatnya dari kehancuran moral, terjerumus terhadap perbuatan maksiat, minuman keras ...... Sikap peduli melindungi kehancuran keimanan dari rakyatnya, kehancuran agama ini..." that he used praise to give a positive effect to the audience regarding the existence of the first mayoral candidate of Gorontalo.

The use of praise to his own mayoral candidate and attack the opponent mayoral candidate which was done chronologically by the speaker in datum 3 and 4 gave a considerable 
consequence to the audience. It allowed the audience to logically think and compare which candidate was better than the other. It surely can persuade the audience to vote for them as mayor and vice mayor of Gorontalo in 2018.

Datum 5:

"Pemerintahan sekarang ada hutang 7,4 miliar di Aloei Saboe. Saya sudah bicara dengan ketua Aloei Saboe, saya tanya kemudian tahun 2014 desember 2017 itu rakyat kota Gorontalo itu berobat ke Aloei Saboe yang tidak membayar itu 5364 orang ya."

In this datum, the speaker told about debt that the current government had to Regional General Hospital of Gorontalo. He said that since 2014 until December 2017, the city government had IDR 7.4 billions debt to Aloei Saboe as the Reagional General Hospital of Gorontalo, and there were 5364 people who had not paid the hospital cost yet. The speaker said that this information was gotten from the head of the Aloei Saboe general hospital.

By considering the content of the datum, the speaker used evidence as persuasive strategy to convince the audience. The kind of evidence the speaker used here is an anecdotal evidence. It was because this evidence was gained only from the information given by someone. It could be seen from the clause "Saya sudah bicara dengan ketua Aloei Saboe" contained in the datum 5, which means "I have talked with the head of Aloei Saboe". From this clause, it can be concluded that the speaker received this report from the head of the general hospital of Gorontalo. However, this evidence also contained numbers, such as in "7,4 miliar" and "5364 orang" which could show the audience that the speaker had good understanding about this data.

The use of evidence here could provide data as an argument for the audience to reasonably consider that the argument the speaker said was rational. It definitely gave important effect for the candidate since it could direct the audience to think the same concept with him. It could then provided a positive impact for the spoken candidate.

\section{PERSUASIVE LANGUAGE USED BY MT AND RFK}

MT and RFK were the second candidates of mayor and vice mayor of Gorontalo city in 2018. It had previously mentioned that MT was the incumbent mayor since 2013. According to the data finding, delivering his political campaign, this candidate often pointed out the projects he had been doing when he served Gorontalo city as the mayor. There were several persuasive strategies used by the candidates which were evidence, logic, attack, appeal to a sense of justice, along with appeal to the hip-pocket nerve. Those strategies are presented in the following explanation.

Datum 6:

“...bukan hanya sebagai janji-janji yang akan saya sampaikan
bukan hanya janji yang akan kami utarakan yang akan kami
sampaikan pada bapak ibu sekalian tapi saya sudah
membuktikan program-program yang saat ini sudah dirasakan
dan dinikmati oleh seluruh warga masyarakat kota Gorontalo."

In this datum, the speaker was the second mayoral candidate, MT, who said that he would like to present his programs which he would realize when he was chosen as a mayor. Additionally, he said that those programs would not be the unrealized promise because in his previous term of serving Gorontalo as a mayor, he had already realized his preceding projects. This utterance was uttered at the beginning of his speech.

Based on the idea of the datum, it could be clearly seen that the speaker used reason and logic as persuasive strategies to persuade the audience. He used this strategy to show the proves 
that he could do reputable program as a mayor. It could certainly bring the audience to believe what the speaker said. The objective of telling this utterance which included in reason and logic strategy was to persuade the audience to vote for him as a mayor of Gorontalo. Furthermore, to support his objective, the speaker additionally presents several evidences, which were also considered as persuasive language strategy, in form of anecdotal evidences. Those data of evidences are presented in the following.

Datum 7:

"tahun ini tahun 2016 di bawah kepemimpinan kami saya tingkatkan dan kami lakukan repitalisasi rumah sakit Aloesaboe meningkatkan pelayanannya baru dokter sekarang sudah ada dokter super ahli jantung dikota gorontalo. Adikny dari sudara Rohi Mokiki namanya dokter viki Mohidi dokter super spesalis

Datum 8: penyakit jantung"

"sekarang saya bangun fasilitas kamar kurang lebih 48 kamar kali 4 orang yang ada dalam kamar kelas tiga tapi kualitasnya sama dengan kelas VIP bapak ibu sekalian ia dibelakang rumah sakit yang berdampingan dengan Gorontalo Kardio Center pusat pengobatan jantung Gorontalo disebelahnya kelas tiga yang ber $A C$ "

Datum 9:

“...pelayanan yang saya berikan kepada anggota masyarakat demi mewujudkan apa yang pernah saya janjikan inilah bapak dan ibu sekalian yang akan kami lanjutkan tahun 2019-20124"

Datum 10:

"saya membangun dan mengembangkan pasar mo'odu yang berdiri megah saat ini, pasar potanga, pasar bulota, itu yang kita kembangkan dan itulah bentuk kepedulian kami bahwa kami benar-benar meberikan perhatian kepada usaha mikro kecil di kota Gorontalo inilah yang akan kami lanjutkan lima tahun yang Datum 11: akan datang"

"tahun 2012 saya memprogramkan apa yang dinamakan ruang terbuka hijau contohnya itu yang ada di mo'odu itu pasar sudah yang menjadi pusat liburan, pusat nyaman untuk masyarakat kota gorontalo bersantai-santai"

Data 7, 8, 10 and 11 are considered as evidences for the reason that the speaker used these to support his previous explanation about the reason why the audience should vote him as the mayor of Gorontalo. In datum 7 and 8, he talked about how he had managed and successfully revitalized the general hospital of Gorontalo, in term of the services, the human resources, as well the infrastructures. Whereas in datum 10, he talked about how he had built and developed the Mo'odu market as one of traditional markets to assist the small industry in Gorontalo city. Moreover, in datum 11, the speaker talked about how he had constructed some green open spaces in Gorontalo city.

Those evidences presented by the speaker, which was the second mayoral candidate, could influence the audience to think that the speaker had qualification in developing their city. The phrase "di bawah kepemimpinan kami saya tingkatkan", "itulah bentuk kepedulian kami...", "sekarang saya bangun fasilitas kamar...", "saya membangun dan mengembangkan pasar mo'odu", and "tahun 2012 saya memprogramkan..." which mean "under our leadership, I improved...", "that was part of our concern", "Now, I build room...", "I develop Mo'odu 
market...", and "in 2012, I made...", showed that the speaker used first person pronoun, such as I and We, to point out that he as the candidate of mayor of Gorontalo city had credibility and could be trusted as the next mayor of Gorontalo. It was supported by the utterance in datum 9 , by saying the utterance in that datum, the speaker wanted to emphasize that he had administered some valuable schemes when he was a mayor. It meant that he had created his own good image to lead the audience critical mind and then decided to vote for him.

Beside reason and logic, and evidence, the speaker also used attack to guide the audience logical idea to be in the same position with him. The datum is presented below.

Datum 12:

"Kata masyarakat "dorang bilang banyak utang" yang utang itu saya diberikan kepercayaan memimpin kota Gorontalo saya mewarisi utang kurang lebih 50 miliar huuuu. Hutang apa itu? Pembangunan terminal yang tidak selesai-selesai jadi tidak ada kaitan sistem saat itu yang mereka tidak tau jadi dirumah sakit itu semua orang berobat Gratis!!"

By evaluating this datum, it could positively be seen that the speaker blamed the former mayor for the debt he was talking about. As it was already explained that the second candidate of Gorontalo mayor, who was the speaker, was the incumbent mayor. Whereas the first mayoral candidate was the former mayor of Gorontalo city, right before the speaker served Gorontalo city as a mayor. From this situation, it could be interpreted that the speaker used attack to accuse the former mayor, who was also his opponent in this mayoral election. The attack strategy used by the speaker here put the audience to have bad judgment to his opponent, and therefore dismissed the opponent's standpoint. It definitely gave a bigger chance to the speaker to be voted as a mayoral candidate of Gorontalo.

Moreover, as language strategy to persuade the voters, the speaker also used appeals to the audience response. According to the data finding, there were two kinds of appealing to the audiences' emotion used by the speaker. They were appeal to a sense of justice and appeal to the hip-pocket nerve.

Datum 13:

"saya buat program bagaimana meningkatkan pelayanan rumah sakit karena dalam pelayanan rumah sakit saya sudah memprogramkan melalui pelayanan dengan kartu sejahtera pelayanan di kota Gorontalo mulai dari puskesmas sampai dengan rumah sakit rujukan itu saya gratiskan tidak perlu bayar."

Datum 14:

"Jadi jangan sampai ada pikiran dari masyarakat karena madidu he bayariyala bo asal-asal botiye pengobatan. Saya tidak mau seperti itu harus titingkatkan pelayanan di rumah sakit. Kita perbaiki sarana ditingkatkan fasilitas perbanyak dokter special dan tentunyaa fasilitas-fasilitas alat kesehatan harus mampu memberikan pelayanan yang terbaik bagi masyarakat termasuk pengobatan-pengobatan yang tidak mampu dilakukan di gorontalo diluar daerah."

Datum 13 and datum 14 are considered as appeal to a sense of justice strategy because in this two data, the speaker told about the citizen's right to be treated the same. In both data, the speaker, as the current mayor of the city as well as the second mayoral candidate, talked about how he managed people who were responsible to give a good services to the citizen, in term of hospital services. By uttering these two data, the speaker wanted to point out that due to the health services, all the citizen had to have the same treatment. No matter what your social status was, when you came to the hospital, you would have the same facilities and services. 
The use of appeal to a sense of justice as persuasive strategy allowed the speaker to influence the audience emotional feeling, and eventually agreed with what the speaker said. It certainly gained a positive response of the audience since the speaker could guide them to be in the same viewpoint with him.

Due to the appealing of the audience's response, there was another strategy used by the speaker. The strategy was appeal to the hip-pocket nerve. The data regarding this strategy are presented in the following explanation.

Datum 15:

“...berapa jumlah biaya yang harus dikeluarkan belum menyangkut masaalah pasien termasuk para keluarga yang mendampingi begitu besar biaya yang dikeluarkan orang yang kayapun orang yang mampupun sulit bapak dan ibu sekalian maka, melalui kebijakan dan program yang kami jalankan saya membengun yang namanya Gorontalo Kardio Center Pusat pelayanan jantung di kota Gorontalo ada di rumah sakit Aloesaboe."

Datum 16:

"Di kota Gorontalo pelayanan kesehatan mulai dari puskesmas sampai dengan rumah sakit rujukan itu tidak dipungut biaya bapak dan ibu sekalian gratis!!”

In these two data, datum 15 and 16, the speaker still talked about hospital services for the citizen. However, in these data, he underlined the health cost problem. He said that the city government, under his service, had built Gorontalo Cardio Center so that the citizens who needed the facility did not have to spend much money because they could use that facility with no cost. To say these utterances, the speaker wanted to make the audience to think that he paid attention to their financial problem.

The speaker appealed to the hip-pocket nerve to make the audience assume that he thought their financial problem. This strategy influenced the audience's positive response then guided them to think that the speaker concern with their issues, particularly hospital cost, and could provide acceptable solution for them.

\section{PERSUASIVE LANGUAGE USED BY RP AND RM}

RP and RM were the third candidate of mayor and vice mayor of Gorontalo in 2018. Different from two previous candidates, who had ever served Gorontalo city as a mayor, these mayoral and vice mayoral candidates were new figures in the city. According to the data findings, in regard with the logical content of the message in the campaign, there were several persuasive strategies used by these candidates to persuade the audience. Those strategies are reason and logic, evidence, attack, and inclusive language.

Datum 17:

"coba liat pasar-pasar Kita ya seperti pasar sentral coba liat semakin hari semakin kumuh setiap hujan sedikit air naik ditempat jual pakaian ditempat jual ikan ditempat jual sayur semuanya seperti kumuh bapak ibu sekalian lantai duanya sudah tutup bagaimana orang dari luar datang mau berbelanja di kota gorontalo sementara keadaan pasar Kita seperti itu betul ya"

The speaker of this datum was the third vice mayoral candidate. He talked about the circumstances of the main traditional market in Gorontalo city, which was Pasar Sentral. He described in detail the condition of that traditional marker, which was so dirty and looked like a slum area. He said how they could attract people from other area to come to this traditional market if the condition was like the slum. 
This utterance was considered as reason and logic strategy to influence the audience. It was because in this datum, the speaker provide a logical reason of a slum appearance of a traditional market would cause a cost damage for the city. This strategy was used to direct the audience to logically think that the speaker's argument was acceptable and needed to be concerned. This logical reason was followed by the solution to the problem the speaker presented, which could also be included in logic and reason strategy. It could be seen in the following datum.

Datum 18:

"Olehnya pasangan Roem Pagau dan Dr. Rusli Monoarfa akan menata ulang Kota Gorontalo akan merubah semuanya akan memperbaiki kawasan-kawasan perdagangan kawasan kaki lima semuanya akan kita tata rapih parkir-parkir kita tata rapih Rumah Sakit Puskesmas seluruh kawasan-kawasan untuk pelayanan umum semuanya kita rata rapi kembali."

This utterance was uttered by the speaker followed the utterance in the previous datum, datum 17. In this datum, the speaker introduced a solution to the problem he said previously. He said when he and his mayoral candidate were elected, they would have rearranged the traditional market, also the other public facilities to make the city be better.

As it was already indicated that this datum was examined as reason and logic strategy. It provided the speaker logical point of view which was supported by facts and common understanding about the problem of public facilities. This strategy was used to link the ideas in datum 17 and datum 18 and to form the audience's critical argument to support the speaker point of view.

Another reason and logic strategies were found in the utterances in the political campaign of third candidate.

Datum 19:

"Bapak Ibu sekalian Anda bicara gratis tetapi pada saat Fakta dan Buktinya sampai di Rumah Sakit susah sekali di layani Bapak Ibu sekalian Olehnya pasangan Roem Pagau dan Rusli Monoarfa salah satunya yang akan kita rubah adalah Rumah Sakit Pelayanannya Kita tingkatkan Dokternya kita akan maksimalkan Perawatnya akan Maksimalkan 24 jam"

Datum 20:

"saya dan Pak Roem sudah punya konsep yang baru Kami akan menyiapakan Dana Cadangan bagi mereka yang tidak punya BPJS sehingga siapapun masyarakat siapapun dia siapapun dia yang masuk Rumah Sakit maupun Puskesmas yang tidak memiliki kartu apa-apa cukup dengan KTP Kota Gorontalo sudah bisa dilayani Bapak Ibu sekalian"

Datum 21:

"kalau kami jadi Walikota maupun Wakil walikota program ini akan kami buat di Kota Gorontalo dan bukan hanya 500 insa Allah sampai 5000 anak-anak SMA SMK yang mengangur akan kita beri tunjangan agar mereka bisa punya pekerjaan jadi caranya adalah mereka ini dilatih nanti BLK (Balai Latihan Kerja) " 
Datum 22:

"kalau kami jadi Walikota maupun Wakil walikota program ini akan kami buat di Kota Gorontalo dan bukan hanya 500 insa Allah sampai 5000 anak-anak SMA SMK yang mengangur akan kita beri tunjangan agar mereka bisa punya pekerjaan jadi caranya adalah mereka ini dilatih nanti BLK (Balai Latihan Kerja)"

These four data were also interpreted as reason and logic strategy to persuade the audience. In data 19 and 21, the speaker told about problems. Successively, the hospital services and unemployment. Whereas in data 20 and 22, the speaker proposed the solution to those two problems if he was elected.

Beside providing rational arguments for the audience to consider, this strategy also allowed them to convincingly assume that the speaker and his mayoral candidate had the ability think about solutions to take care of problems appeared in the city. It surely gave benefit to the candidates since it could influence the audience's critical thinking to be in the same position with them.

When using reason and logic as persuasive strategy, the speaker also occasionally combined it with attack strategy as shown in the following data.

Datum 23:

"Jadi kalau mau jadi Walikota harus tau dulu apa potensi Kota Gorontalo olehnya kita lihat perkembangan sudah beberapa periode Walikota Kota Gorontalo tidak pernah berubah karena tidak pernah meliat apa potensi Kota Gorontalo Bapak Ibu sekalian"

Datum 24:

"Jangan-jangan Boalemo yang umurnya baru 18 tahun akan lebih baik dari kota yang umurnya sudah mau sampai 300 tahun. Karena apa? Pemerintahnya tidak peduli dengan perkembangan Kota Bapak Ibu sekalian Oleh sebab itu tidak ada pilihan lain kalau Kota mau Berubah jangan lagi dipimpin oleh itu-itu lagi Maka kita perlu perubahan Cari Pemimpin yang Baru dari pasangan nomor 3"

As reason and logic strategy, in this two data, the speaker talked about how the proper mayor should be. In datum 23, he said that to be a competent mayor, one should know potentials of the city. He then claimed that the current city government did not have capability in recognizing those potentials of the city for the reason of there was no changes happened in Gorontalo city in several years. This kind of argument was considered as attack strategy because the speaker criticize the current city government who was also one of his opponent. He then additionally said another attack, as shown in datum 24, which said that not to vote for the same mayor who had ever served Gorontalo to have a better city in the future, we had to change the leader, who referred to third candidate of mayor and vice mayor of Gorontalo 2018.

This combination of strategies could lead the audience to reasonably think that the speaker arguments were objectively correct, and eventually brought them to point out the positive things of the speaker's side and the negative things of his opponents.

Additionally, the speaker also used evidence as another strategy to influence the audience. It helped the speaker to provide trusted data for the voters in order to have them trust what the speaker said. The utterance contained this strategy is presented below. 


\section{Datum 25:}

Bapak Ibu sekalian Kami mendengar Rumah Sakit Kita ini ada masalah sedang terbebani hutang kalo baca di koran 7,5 Miliar ini saya baca di koran halaman depan koran Gorontalo Post Sementara Rumah Sakit ini adalah pusat pelayanan di Bidang Kesehatan belum lagi kalau orang yang tidak memiliki kartu apa-apa kadang kala tidak dilayani kadang kala membayar dulu baru dilayani kase jaminan dulu baru dilayani Maka kedepan ini harus dirubah.

As it was seen from the content of datum 25, the speaker told about debt that the city government had to the regional general hospital of Gorontalo. He said that he got the information from the local newspaper that the government had IDR 7.5 billions to the hospital. For that reason, some citizens were not appropriately serviced. Therefore, this situation should be reorganized in the future.

From the idea of this datum, it could be seen that the speaker provided evidence for what he had said. This strategy was used by the speaker to show the audience that he was able to give trusted evidence to the thought he shared. It eventually gave influence to the audience to have the similar opinion with him.

In addition to the logical content of the message, the speaker also appealed the audience's response as persuasive language strategy. Regarding this, there were three different strategies used by the speaker, which were appeal to a sense of justice, appeal to audience's emotion, and appeal to patriotism. The data contained these strategies are sequentially presented below.

Datum 26:

"setelah mereka wisuda pemerintah seakan-akan biarkan bahwa ini adalah urusan masing-masing bapak ibu sekalian maka pasangan rama sudah punya konsep"

Datum 27:

"Bapak ibu sekalian padahal uang yang rakyat keluarkan untuk mereka kuliah itu sudah puluhan juta pemerintah seakan-akan tidak mau tahu jangan-jangan ada yang keluar kata "sapa suru ada kuliah" padahal mereka ini kita selalu ingin mencitacitakan ingin mencerdaskan bangsa yang tidak kuliah bagaimana caranya harus kuliah"

In data 26 and 27, the speaker talked about the youth unemployment in Gorontalo and how the current government seemed not to have any consideration about that. To be clearly explained, by saying utterance in datum 26 , the speaker wanted the audience to feel that he also thought about their problems regarding the youth unemployment. He demanded them to believe that the youth should be treated better and the speaker with his mayoral candidate had already had plan to solve the problem. This utterance was considered as appeal to a sense of justice because the speaker's objective was actually to lead the audience to feel that they needed to have the same treatment from the government.

Moreover, in datum 27, the speaker allowed the audience to have negative emotional response in regard with the educational fee they had to spend. By this utterances, he wanted to say that the current city government did not care how much money they spent to educate their children. This utterances surely guided the audience to be angry so that the speaker could take advantage from their response and presented their plan to solve the problem and eventually persuade the audience to be in the same viewpoint with the speaker. 


\section{CONCLUSION}

The use of persuasive language was considered to be an important and useful way when it came to political campaign. This idea was developed because according to experts, using persuasive strategies to influence the voters to be in the same viewpoint with the politicians could be an effective weapon for them.

In this study, the speeches of three candidates of mayor and vice mayor of Gorontalo 2018 were analyzed. The result showed there were some strategies used by the speakers to persuade the audience. Generally, the three speakers used the similar strategies, namely reason and logic, evidence, attack, appeal to a sense of justice, appeal to the hip-pocket nerve, appeal to patriotism, repetition, and colloquial language. These three speakers had different political background, particularly whether or not they had ever served Gorontalo city as mayor. This situation was believed could be a factor to influence the way they used strategies to persuade the audience.

The first candidate was the former mayor of Gorontalo, who had ever served Gorontalo since 2008 until 2013, before he was defeated by the second candidate of mayor. For this reason, the first candidate often used attack as persuasive language strategy and the attacks were generally pointed out to the second candidate. Beside attack, the first candidate also used evidence to show the audience that he had an authority of what he said, as well as repetition to emphasize the arguments he suggested. The second candidate was the incumbent. Therefore, he often used evidence to show the audience that he was capable to serve Gorontalo one more time since he had done some successful projects for Gorontalo to be better. He also used reason and logic to support his arguments. However, the third candidate was a new figure for Gorontalo city. Consequently, when delivering his campaign, he often used reason and logic to show the audience that he was able to identify some problems the city had then propose some solutions for the issues by using reason and logic strategy. Beside those strategies that had been mentioned, these three candidates also used strategies to appeal the audience's emotion. Those strategies were appeal to a sense of justice, appeal to the hip-pocket nerve, appeal to patriotism.

\section{REFERENCES}

Baker, M. (n.d) Aristotle's Three Modes of Persuasion. Aalto University School of Business. https://mycourses.aalto.fi/pluginfile.php/217778/mod_resource/content/1/Aristotles\%20three\%20modes \%20of\%20persuasion.pdf

Creative Content Australia. (n.d.). Persuasive Language: Teaching Resource (A Guide to Understanding Persuasive Language).https://www.creativecontentaustralia.org.au/announcements/persuasive-languagerelease

Edlund, J. (n.d). Three Ways of Persuade. http://www2.pylusd.org/par/lbegin/Writing/12thRhetoric_OpEd_Page Readings.pdf

Georgakopoulou, A., Goutsos, D. (2003). Discourse Analysis: An Introduction. Manchester: Edinburg University Press.

Kulo, L. (2009). Linguistic Features in Political Speeches. 2009:038 - ISSN: 1402-1773 - ISRN: LTU- CUPP09/038 - SE.http://www.diva-portal.org/smash/get/diva2:1028973/FULLTEXT01.pdf

Moore, A. (2003). Language and power. http://www.universalteacher.org.uk/lang/power.htm.

Pacho, Titus O. (2015). Exploring Participants' Experiences Using Case Study. International Journal of Humanities and Social Science. Vol. 5, No. 4; April 2015. http://www.ijhssnet.com/journals/Vol_5_No_4_April_2015/5.pdf.

Razaei, S., Nourali, N. (2016). Language and Power: The Use of Persuasive Techniques in Iran and U.S. Presidents Speeches. Journal of Language Teaching and Research, Vol. 7, No. 6, pp. 1203-1209, November 2016. ISSN 1798-4769.

https://pdfs.semanticscholar.org/81ba/16b65764c2417b47251cce3be74ef54bcc3c.pdf 